\title{
NUEVAS APORTACIONES A LA INTERVENCIÓN DE MAELLA EN LA DECORACIÓN DE LA COLEGIATA DE LA GRANJA*
}

\author{
POR \\ JOSÉ MANUEL DE LA MANO
}

\begin{abstract}
Mariano Salvador de Maella was commissioned to plan a set of fresscoes for the collegiate church at the royal palace of La Granja de San Idefonso. The decoration of the church's interior had remained unaccomplished at Giambattista Tiepolo's death in 1770. The full complexity of the history of this commission has hitherto remained somewhat obscure, but a through search of the archives at both San Ildefonso and Madrid now allows the story to be told in full.
\end{abstract}

En el transcurso de la segunda década del siglo XVIII y bajo el reinado de Felipe V se erige en San Ildefonso su Real Colegiata con la advocación de la Santísima Trinidad. Desde el mismo instante de coronamiento de la construcción, en el seno de su cabildo emergen las peticiones para la configuración del ornato interior mediante estucos y frescos. No obstante hasta época de Carlos III los canónigos no encuentran un ambiente propicio a la reanudación de las obras. En un gesto de benevolencia el monarca emplaza a su arquitecto Francisco Sabatini para la concepción del diseño. Más adelante y de igual modo, se servirá para su realización de otros artistas también adscritos a la nómina de palacio, como Roberto Michel o Giambattista Tiépolo.

Las expectativas suscitadas en la Granja se desmoronan súbitamente a raíz del fallecimiento del veneciano en la madrugada del 27 de marzo de 1770. Nada mas anunciarse al cabildo el fortuito imprevisto, se acuerda contactar con su comisionado en la capital, para «que luego se traslade la Corte a Madrid se presente al Sr. Marqués de Grimaldi suplicándole lo haga presente a S.M. para que se digne a nombrar otro en su lugar» ${ }^{1}$. En efecto sobre estas fechas discurría una de las escasas estancias reales en el Palacio Nuevo, a caballo entre la jornada del Pardo y la de Aranjuez. En este año de 1770, Carlos III no se persona en Ma-

Este artículo está extraído del trabajo de investigación «G.B. Tiépolo, Francisco Bayeu y Mariano Salvador de Maella en la Colegiata de la Santísima Trinidad de la Granja», que se presentó en septiembre de 1994 en el Departamento de Historia del Arte Moderno de la Universidad Complutense de Madrid, bajo la dirección del Profesor don Jesús Urrea.

1 Archivo de la Colegiata de San Ildefonso (a partir de ahora A.C.S.I.) Libro 2. de Acuerdos communes del Cabildo de la Insigne Real Iglesia Colegial de la S. Trinidad de San Ildefonso 1.o octubre 1750-17 enero 1772, f. 436. En el libro de actas capitulares se anota esta resolución con fecha del 24 de marzo de 1770 . No obstante debe ser una confusión del canónigo secretario pues todavía no había fallecido el veneciano. 
drid hasta finales de la primera semana de abril. Como se le había ordenado Ramón Galamino acude presto a entrevistarse con el secretario de Estado al establecerse allí la corte.

Todavía no alcanzamos a descifrar el motivo por el que este ministro, a pesar de haber requerido ya a Sabatini su parecer sobre el artista más idóneo para reemplazarlo ${ }^{2}$, al canónigo «a las primeras dio a entender que por parte de S.M. era negocio concluido con la muerte de Tiepolo» ${ }^{3}$. De inmediato en su entrevista siguiente ya se desdice al transmitirle el dictamen real de 8 de abril de que concurran a Palacio los artistas Maella y Bayeu con Sabatini y Grimaldi para departir sobre los frescos ${ }^{4}$.

Transcurrido algún tiempo, Ramón Galamino comunica a Francisco Javier Calvo el día 18 la asignación para las obras en esta ocasión de dos pintores ${ }^{5}$. Pero el entusiasmo inicial que suscita en la Granja esta noticia pronto se desvanece al advertírseles «que no podían venir en este verano inmediato por tener que evacuar otros encargos de Aranjuez» ${ }^{6}$. En efecto en la total disponibilidad del valenciano se interponían diversas comisiones para el convento de san Pascual Baylón. Con destino a su refectorio estaba ya concluyendo una Última Cena ${ }^{7}$ y también salida de su obrador se pretendía emplazar en el claustro alto de dicha fundación una Inmaculada Concepción ${ }^{8}$. Ante tal perspectiva los canónigos acordarán persuadir por caminos dispares al monarca para que les favoreciera y otorgara prioridad ${ }^{9}$.

A mediados de junio de 1770 los machacones llamamientos del cabildo conquistan su objetivo. Sebastián de Yndaburu previene a Francisco Javier Calvo para que al «oficial que embían los Pintores se le faciliten los Peones y demas cosas necesarias para sus cosas, como assimismo un quarto, y cama a donde estar» ${ }^{10}$. El 27 de julio ya se efectúan las gestiones precisas para que al artista «se aloxara, costeara el viaje, y mantuviera a él y a las personas que trajera con la decencia correspondiente al Cabildo» ${ }^{11}$.

2 Las gestiones de Grimaldi para sustituir a Giambattista Tiépolo ya fueron estudiadas en: De la Mano, José Manuel. «Francisco Bayeu y los frescos de la Colegiata de la Granja». Catálogo Exposición Francisco Bayeu 1734-1795, Zaragoza, 1996.

3 A.C.S.I. Caja 23 Leg. 2 n.o 1. Documento citado por Martín, Pompeyo. Las pinturas de las bóvedas del Palacio Real de San Ildefonso. Madrid: Patrimonio Nacional, 1989, pp. 243-244.

${ }^{4}$ Archivo General de Palacio (a partir de ahora A.G.P.) Caja 18.221 Exp. n.o 10. Documento citado por primera vez en Morales y Marín, José Luis. Los Bayeu. Zaragoza: Caja de Ahorros de Zaragoza, Aragón y Rioja, 1979 , p. 114.

5 A.C.S.I. Caja 23 Leg. 2 n.․ 1 . Martín, op. cit., pp. 244-245.

6 A.C.S.I. Libro 2. ${ }^{\circ}$ de Acuerdos Comunes..., f. $436 \mathrm{v}$.

7 En 1836 se traslada la parroquia de Aranjuez a dicho convento y se intentará vender algunas pinturas que no estaban al culto. Hacia estas fechas esta «Última Cena» de Maella se encontraba en el claustro. En el primer inventario hecho en julio de 1836 por José Antonio Muñoz se desconoce su autor pero se le dan las medidas de 5 $\times 10$ pies. El 17 de agosto Francisco Martínez Salamanca vuelve a hacer una nueva relación de cuadros en la que atribuye el cuadro a Francisco Bayeu, tasándolo en 600 reales. Será el pintor Vicente López quien finalmente en el mes de septiembre lo asigne a Maella «hecho para las religiosas carboneras» y lo tase en 6.000 reales de vellón (A.G.P. Caja 14.328).

8 «Señor Don Franco. (Sabatini) necesito de casa de trapaga una onza de ultramar para el quadro de la Concepcion que estoi asiendo para el Convento de Aranjuez. Madrid y Mayo 1 de 1770. Mariano Maella» (A.G.P. Caja 17.440).

9 En la sesión celebrada el día 28 de abril de 1770 «se resolvió con unánime consentimiento se escribiesen las gracias al Sor. Marques de Grimaldi ... También se acordó escribir a don Bernardo Iriarte oficial de la misma secretaria manifestándole el agradecimiento del Cavildo por lo que había cooperado en este asunto ... Y que por si el Sor. Galamino estaba ausente se le incluyese la carta a don Sebastián de Yndaburo haciéndole el mismo encargo en su ausencia». En esta reunión de los canónigos se referieren al veneciano como «Francisco Tiépolo» probablemente confundiendo su nombre con el de Sabatini. A.C.S.I. Libro 2. ${ }^{\circ}$ de Acuerdos communes..., f. 437.

${ }^{10}$ A.C.S.I. Cajón 23 Leg 2 n. ${ }^{1} 1$

1 A.C.S.I. Libro 2. ${ }^{\circ}$ de Acuerdos communes..., f. 443. 
La comparecencia de Maella procedente de Madrid no se materializa hasta la primera semana del mes siguiente ${ }^{12}$. A pesar de ello el 10 de agosto el canónigo fabriquero todavía ignoraba su identidad; «de los dos Pintores de Camara nombrados por S.M. para pintar la Iglesia solo habia venido el uno que habia dicho no sabia quando podria venir» ${ }^{13}$. Para el alojamiento del valenciano y su criado, se habilita un cuarto ${ }^{14}$ en el interior de la propia Colegiata situado sobre el Panteón de Felipe $\mathrm{V}^{15}$.

Era una práctica bastante habitual en las labores al fresco que la llegada del maestro se viera precedida en algunas semanas por la de sus oficiales. La razón de ser de esta actuación no era otra que la de ir avanzando su trabajo para que Mariano Maella pudiera tomar en seguida los pinceles. Hacia estas mismas fechas Antonio Niño ya les asiste a encaramar a «los andamios los materiales» ${ }^{17}$. No se guarda constancia documental certera de la bóveda por la que se comienza, aunque existe la sospecha de que el pintor aborda en primer lugar la ubicada sobre el altar mayor al hallarse allí ya instalados los andamios ${ }^{18}$.

Enteramente arruinados los frescos originales, la única crónica fidedigna del ciclo allí reproducido nos la facilitan ciertas descripciones. De entre todas ellas la que los reseña con mayor detenimiento es quizás la de Breñosa y Castellarnau, que en las postrimerías del siglo XIX apostilla:

«Los platillos de las cuatro bóvedas, rodeadas de un cerco moldurado, fueron pintados al fresco por Maella con los siguientes asuntos: en la bóveda de la tribuna, la aparición de Santa Leocadia á San Ildefonso; en las de los brazos trasversales de la cruz, la Purísima Concepción y Santiago combatiendo contra los infieles; y en la del presbiterio, un coro de ángeles» ${ }^{19}$.

En las Bibliotecas del Palacio Real ${ }^{20}$ (Fig. 1) y Nacional ${ }^{21}$ (Fig. 2) se custodian unos esbozos muy similares de «ángeles músicos y cantores», que con toda probabilidad se concibieron

12 Entre las cuentas que se presentan en el mes de agosto a Manuel Bueso hay una partida por valor de 532 reales «que importó el coche en que vino el Pintor dn. Mariano Maella y gasto que hizo en el camino». A.C.S.I.

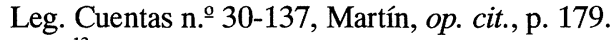

13 A.C.S.I. Libro 2. ${ }^{\circ}$ de Acuerdos communes..., f. $444 \mathrm{v}$.

14 Recibo por «... quarenta y dos varas de lienzo pintado para cortinas del quarto, y cama del pintor». A.C.S.I. Leg. Cuentas n. ${ }^{\circ}$ 30-140, Septiembre 2. Semana.

15 «Abone á los Mozos que subieron los Baules del Pintor al quarto que está encima del Panteon siete rs. vn.». A.C.S.I. Leg. Cuentas n. ${ }^{\circ}$ 30-137.

${ }_{16}$ Este equipo de trabajo estaba integrado por el oficial Antonio María, que fue preparando el mortero, y el moledor que trajo consigo los colores. El grupo lo completaban dos peones, uno llamado Luis que vino de Madrid y otro José Garrote que se contrató en el mismo San Ildefonso.

${ }_{17}$ A.C.S.I. Leg. Cuentas n. ${ }^{\circ}$ 30-140.

18 «Señor Don Franco. Alcozer, sirvase Vd. pagar a don Antonio Niño, tres mil rs. de vn. con los que, y treinta y seis mil rs. de la misma moneda que tiene recividos antecedentemte. como consta de libramientos, quedan totalmte. satisfechos los Andamios, Blanqueos, Escodamientos, Boveda y Citara qe. se ha hecho sobre el Retablo mayor, y perjuicios qe. se le ha ocasido, con motivo de suspension unas veces, y otras de aceleracion de dhos. andamios, segun las ordenes, ya de S.Md. y ya de la Junta ... San Ildefonso y Mayo 2 de 1770». (A.C.S.I. Leg. Cuentas n. ${ }^{\circ}$ 30-108). También sobre estas fechas se ordena a Manuel Matilla «desazer los adornos de las puertas de junto a el altar Mayor». Recibo fechado el 5 de septiembre de 1770. A.C.S.I. Leg. Cuentas n. ${ }^{\circ}$ 30-138.

19 Breñosa, Rafael y Castellarnau, Joaquín M. e. de. Guía y descripción del Real Sitio de San Ildefonso. Madrid: Sucesores de Rivadeneyra, 1884, p. 136.

20 Este diseño en lápiz negro, pluma y aguada sepia sobre papel verjurado mide $280 \times 254 \mathrm{~mm}$. Díaz Gallegos, Carmen. Los álbumes de dibujos de Fernando VII. Madrid, 1990, t. II, pp. 466-469. (Tesis doctoral inédita, U.C.M.).

${ }_{21}$ De la confrontación de ambas soluciones destaca como en los del Palacio Real el efecto de sombras obtenido a través de la aguada es sustituído aquí por un concienzudo rayado a lápiz $(177 \times 362 \mathrm{~mm}$.). Barcia, Ángel M. . Catálogo de la colección de dibujos originales de la Biblioteca Nacional de Madrid. Madrid: Biblioteca Nacional, 1906, p. 218. Mollinedo, Dolores. «Algunos dibujos de Mariano Salvador de Maella». Archivo Español de Arte XLVI, n.. 182,1973 , pp. 146-148. 
para decorar dos bóvedas distintas. Su existencia permite insinuar la hipótesis de que la idea inicial para la zona asignada a Maella en la Colegiata difiera de la solución aquí descrita. El proyecto original pudo alterarse sobre la marcha, conminando al artista a ornamentar con estas escenas angélicas sólo el área sobre el altar mayor. Como si de un acto reflejo se tratara el valenciano toma el lápiz y casi con un simple rasguño plasma sobre el papel otra nueva composición. Por suerte al aproximar la pareja de dibujos de la colección Carderera emerge esta tercera instantánea (Fig. 3). Esta nueva posibilidad se irá modelando a través de sucesivos estadios como el boceto del museo de Bellas Artes de Zaragoza (Fig. 4). Aunque al contemplar el modelli definitivo ${ }^{22}$ (Fig. 5), se constata como la esencia y fuerza de su diseño radicaba ya en estos fugaces trazos aquí rescatados.

El pintor permanecerá en la Granja hasta comienzos del mes de noviembre de $1770{ }^{23}$. Todo su equipo de trabajo le acompaña en su retorno a Madrid, a excepción del peón que alarga su estancia hasta la segunda semana de diciembre para asistir en la construcción de la escalera de la torre de la Colegiata ${ }^{24}$.

No obstante el palmario año de génesis del engalanamiento al fresco de estas bóvedas será 1771. Recien inaugurado el mes de enero, en la Granja emergen los trámites ineludibles para el aposentamiento de los dos Pintores de Cámara ${ }^{25}$. Mientras tanto Maella permanecía en Madrid ultimando los bocetos, que en el curso de la jornada en Aranjuez son presentados al monarca inquiriendo la aquiescencia real ${ }^{26}$. A pesar de acabar de ser llamado a ocupar la plaza de teniente director de Pintura en San Fernando, el valenciano es de nuevo el primero en acudir a su cita con los andamios en la Colegiata, para retomar las labores emprendidas hacía tan sólo algunos meses. En torno a las postrimerías de abril, ya se recibén en San Ildefonso ciertas pertenencias del artista procedentes de la capital ${ }^{27}$. De igual modo y en análogas fechas se facilita acomodo a su moledor de colores y a un peón ${ }^{28}$, antesala de la comparecencia del maestro el 8 de mayo ${ }^{29}$. Paso a paso se irá completando su equipo de trabajo con las progresivas incorporaciones del oficial y a la semana ulterior de otro peón ${ }^{30}$.

Simultáneamente se formaliza el primer viaje de Francisco Bayeu a este Real Sitio ${ }^{31}$, escoltado como el anterior por sus colaboradores. Al afrontar los canónigos el sostenimiento de

22 Óleo sobre lienzo, $40 \times 68 \mathrm{cms}$.

23 El recibo del «coche que condujo á don Mariano Maella Pintor de Camara de S.M. á Madrid» tiene fecha del 5 de noviembre de 1770. A.C.S.I. Leg. Cuentas n.ำ 30-156. Martín, op. cit., p. 245.

${ }^{24}$ A.C.S.I. Leg. Cuentas n. $\stackrel{0}{30-176 .}$

25 El 23 de enero Francisco Alcozer abona por disposición del canónigo fabriquèro al mozo Fernando Ramos «... mil trescientos y once reales de vellon para que pague varias cosas que se han comprado quando los Pintores esta proxima Primavera a pintar Nuestra Iglesia...». A.C.S.I. Leg. Cuentas n.ํ 30-185.

${ }^{26}$ A.C.S.I. Correspondencia Apoderados.

27 «... Aboné a los Mozos del Ordinario de Andrés de Torres, ocho reales vellón que dijeron importaba el trabajo que habian tenido en Madrid, por llevar á la posada los trastos que en el viaje de esta semana habían traído del pintor desde la casa de éste á la dicha Posada...» (A.C.S.I. Leg. Cuentas n. ${ }^{\circ}$ 31-75, Abril 3ª Semana).

28 «... Aboné al ordinario de Segobia, que trajo a los dos referidos desde Madrid, sesenta reales vellón para traerlos. Aboné a los dos referidos por el gasto que hicieron en el camino desde Madrid á este Sitio veinte reales de vellón». (A.C.S.I. Leg. Cuentas n.o 31-75, Abril 3. a Semana).

${ }_{29}$ A.C.S.I. Leg. Cuentas n. ${ }^{\circ}$ 31-69. Martín, op. cit., p. 250.

30 «... Aboné al ordinario el Sitio, por haber traído desde Madrid á este Sitio, un Peón del Pintor Maella y dos cargas de cajones del mismo pintor todo para pintar este en Nra. Rl. Iglesia, ciento y veinte reales vellón. Aboné al referido Peón que ha venido esta semana desde Madrid por su gasto de comer en el camino catorce reales vellón...» (A.C.S.I. Leg. Cuentas n.ำ 31-76, Mayo 2.. Semana).

${ }^{31}$ El aragonés había permanecido enfrascado en otras comisiones del monarca. El 5 de marzo de 1771 Sabatini solicita un coche a Agustín de Lanz, «pa. yr de orden del Rey el Pintor de Camara Don Franco. Bayeu a el R1. Sitio del Pardo mañana 6 del crrte. a una dilixa. de su Real servo.» (A.G.P. Carlos III Leg. n.o 124). 

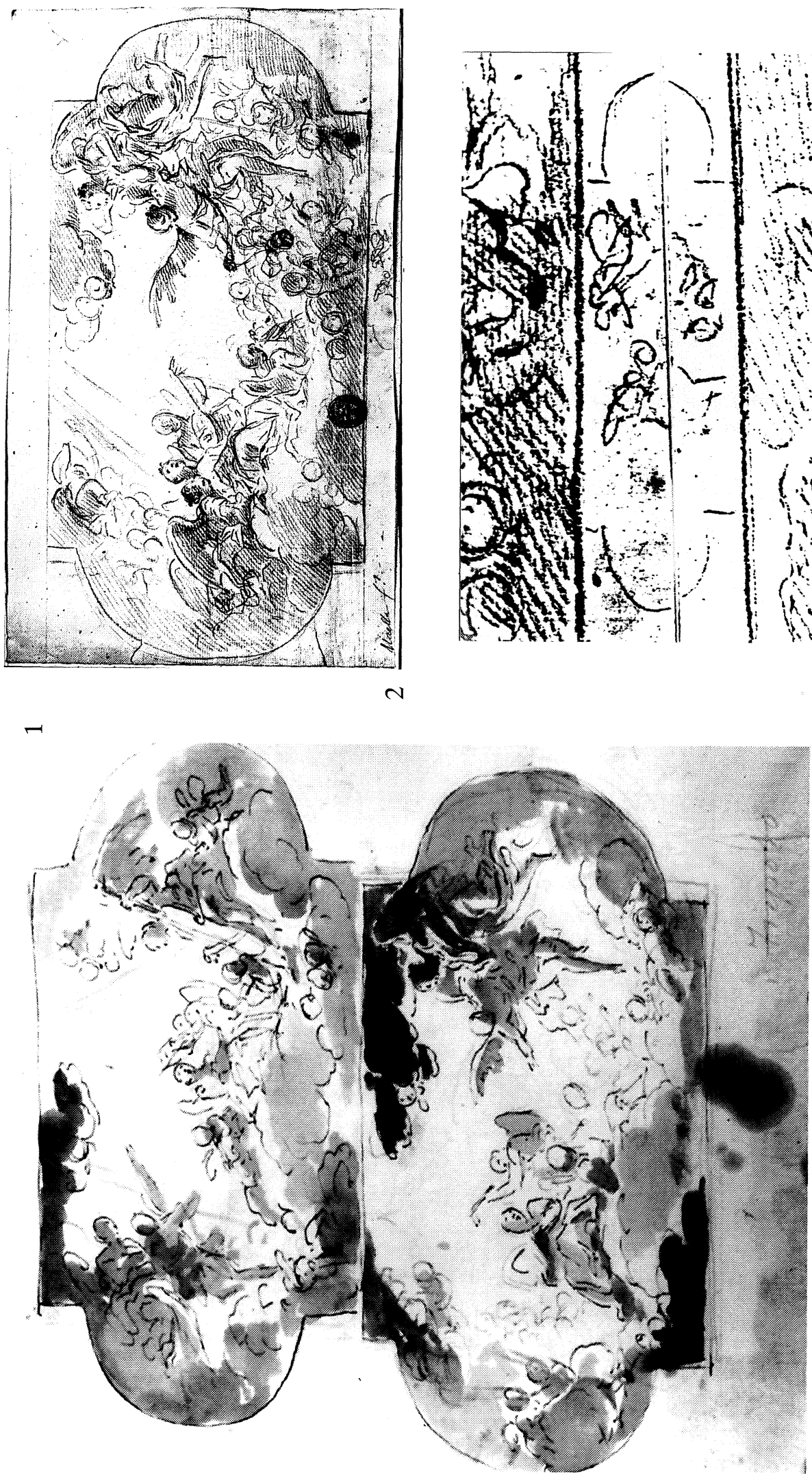

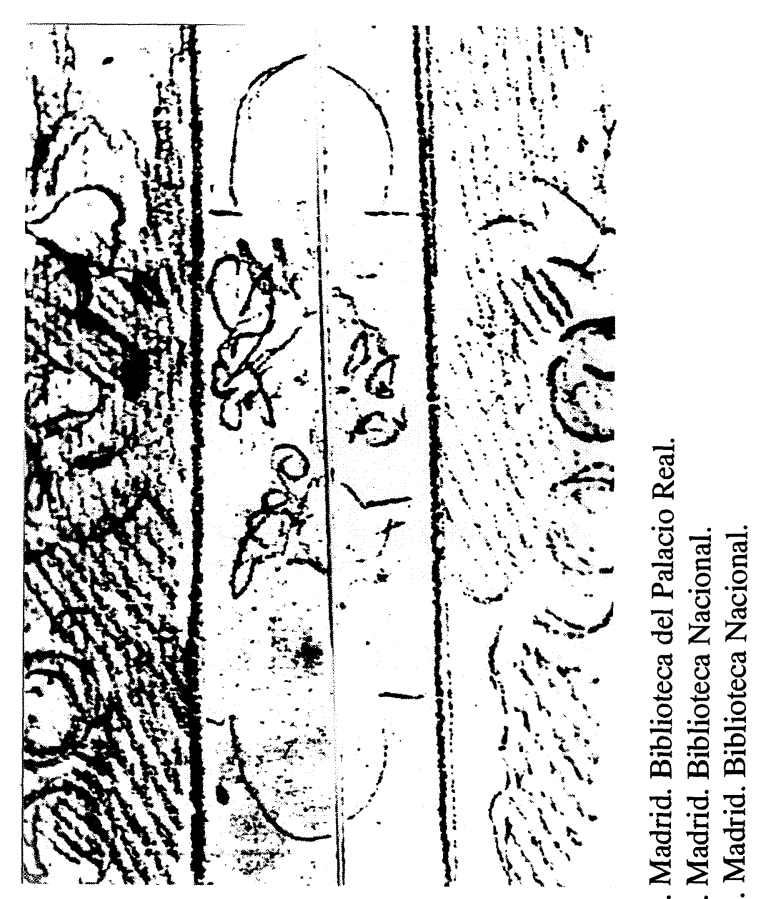

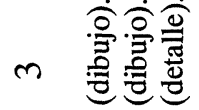

产 $\hat{\hat{\omega}}$

ฮี 등

is 2 iे

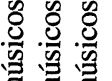

范范

过 $\frac{0}{0}$

定安安

ष

忌总亮

新奈

$8 \approx$

홍 흄

荡苛

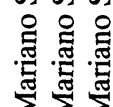

-ivi

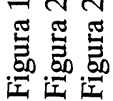



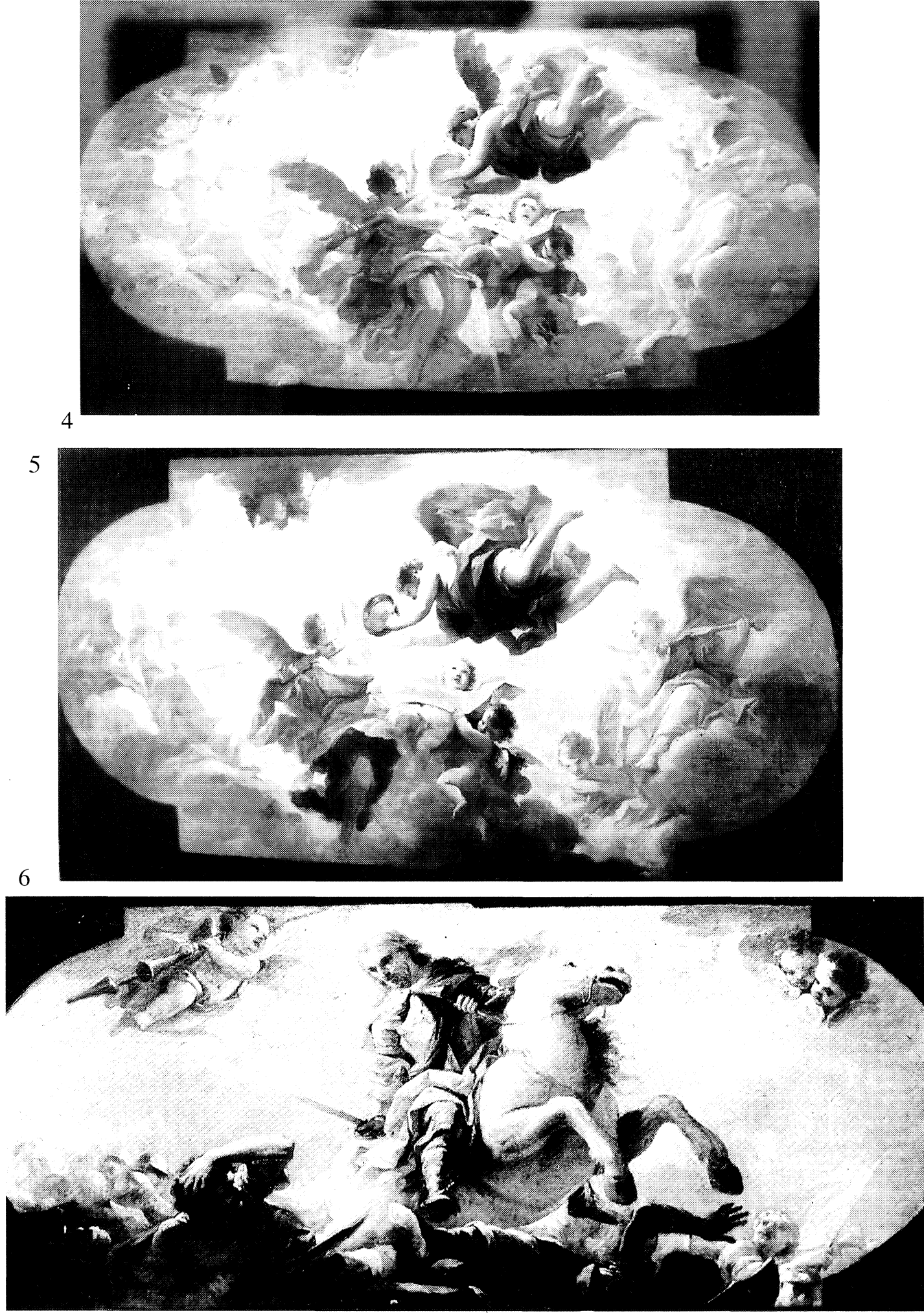

Figura 4. Mariano Salvador de Maella, «Grupo de Angeles músicos y cantores». Zaragoza. Museo de Bellas Artes. Figura 5. Mariano Salvador de Maella, «Grupo de Ángeles músicos y cantores». Madrid. Colección particular. Figura 6. Mariano Salvador de Maella, «Santiago Matamoros». Nueva York. Metropolitan Museum. 
ambas estancias, bastante más prolongadas que las del pasado año, se opta por arrendar sus viviendas a los propios vecinos. Maella será alojado en casa de Diego de la Cueva ${ }^{32}$, costeando integramente el cabildo el amueblamiento de sus habitaciones ${ }^{33}$. El 5 de julio el valenciano procede a traer de Madrid a su esposa María González Velázquez y a su hija, probablemente al advertir que el aragonés había sido autorizado a desplazarse hasta la Granja con toda su familia. Es ante esta alteración de la situación del pintor, cuando el cabildo sopesa el medio más apropiado de abonar su manutención. Las alternativas que se estuvieron barajando fueron las de «dejar a la discrección de dicho Sor. o bien darle un tanto diario o pagarle el gasto que haga» ${ }^{34}$.

Es evidente que Mariano Salvador de Maella y Francisco Bayeu pugnarán en múltiples encargos regios en el transcurso de sus trayectorias artísticas. Pero los frescos de esta capilla palatina se erigen en una de las primeras oportunidades de medir sus fuerzas, trabajando en andamios contiguos. Mientras su competidor emprende la decoración de la cúpula, el valenciano seguramente retomará sus quehaceres con las escenas sobre los brazos del crucero. Hoy en día estas bóvedas lucen sendos grupos de ángeles plasmados allí en los años cinquenta de nuestro siglo por Horacio Ferrer. No obstante como ya se ha subrayado, en origen las imágenes que se concibieron para estos espacios fueron la Inmaculada Concepción ${ }^{35}$ y Santiago Matamoros (fig. 6) ${ }^{36}$.

Se ignora si fue la enorme amplitud de la escena o la complejidad de su composición, lo que obligó al valenciano a postergar la bóveda ubicada sobre el coro, tornándose así en un genial broche de oro a su intervención en las obras. Nuestro artista ya se había encontrado con anterioridad en la obligación de interpretar este episodio de san Ildefonso y santa Leocadia

32 «... Sirvasse Vd. en virtud de esta, y recivo entregar a el Sr. Dn. Diego de la Cueva la cantidad de mil, seiscientos, y quarenta y qtro. rs. vn., importe de cinquenta, y seis dias por veinte, y quatro rs. vn. de la Habitacion de su cassa, q. há echo el Pintor Maella, y de otros cinquenta, y dos dias fuera de jornada, por trescientos rs. en total...» (A.C.S.I. Leg. Cuentas n. ${ }^{\circ}$ 31-54).

${ }^{33} \mathrm{Al}$ comienzo de su estancia en la Granja las camas todavía no estaban terminadas y durante 28 días a los artistas se les facilitaron unos camastros alquilados. En el archivo de la Colegiata se conservan pagos incluso de gastos tan menudos como: «30 cerámicas de Talavera para Maella». El desembolso más importante fue el de mobiliario, del que transcribimos como muestra un recibo: «Señor Dn. Ramon de Galamino Canonigo thesorero sirvase Vd. entregar á Fernando Ramos, Mozo de fabrica de Nuestra Real Iglesia trescientos treinta y seis reales vellón para que satisfaga el importe de tres docenas de sillas de Paja, que se han comprado para las abitaciones de los Pintores que estan pintando nuestra Real Iglesia las dos docenas son grandes a precio de diez reales silla, y la otra docena de pequeñas á ocho reales silla; que tomada la razon del contador y recivo se le avonaran á Vd. en cuentas generales. San Ildefonso y Julio 6 de 1771. Dr. Dn. Phelipe Antonio Solano» (A.C.S.I. Leg. Cuentas n. ${ }^{\circ}$ 31-68). Al concluir los frescos el Cabildo decide repartir entre los pobres de la parroquia todo lo que había sido adquirido para los pintores.

${ }^{34}$ A.C.S.I. Libro 2. de Acuerdos communes..., f. 501.

Finalmente se decide ir abonando todos los recibos que Maella vaya presentando (A.C.S.I. Leg. Cuentas n.. 31, 44-58).

35 Morales y Marín, José Luis. Mariano Salvador Maella. Madrid: Ed. El. Avapies, 1991, p. 62. Mencionó, aunque sin reproducirlo, como boceto para esta bóveda un óleo de $27 \times 64 \mathrm{cms}$. de tratarse del cuadro aparecido recientemente en el mercado, Sotheby's: Colonnade. Old Master Paintings. Londres (19-20 de noviembre de 1996) lot. 112. Correspondería más bien a una copia de taller de una composición del valenciano.

${ }_{36}$ El 4 de mayo de 1764 el marqués de Grimaldi informaba el duque de Béjar como: «La Congregación del Apóstol Santiago, Patrón de España, ha pedido al Rey N.S. permita que el Príncipe N.S. y Señores Infantes entren en el número de los Congregantes. S.M. ha convenido en ello» (A.G.P. Carlos IV (Príncipe) Leg. n.o 1). El boceto para esta bóveda ha sido recientemente identificado entre las obras atribuídas a Corrado Giaquinto en el museo Metropolitan. D’Orsi, M. Corrado Giaquinto. Roma, 1958, p. 102. Morales y Marín, José Luis. Mariano Salvador Maella. Vida y obra. Zaragoza: Ediciones Moncayo, 1996, p. 254. 
en un concurso de la Academia San Fernando ${ }^{37}$. A pesar de ello, en la Granja tendrá que adecuar la distribución de las figuras al encuadre que le brindaba el marco de estuco. Todo su planteamiento general se recompone a través del dibujo que se preserva en el museo del Prado (fig. 7) ${ }^{38}$. Al cotejar este bosquejo con el de la Academia se observa como en su nueva interpretación la imagen del santo titular del Real Sitio cobra lógicamente un mayor protagonismo frente a la del rey Recesvinto. El valenciano parece no quedar complacido con su primer esbozo de la imagen de san Ildefonso y lo medita aparte con mayor detenimiento (fig. 8) ${ }^{39}$. Aunque siempre se reproduce como modelli del valenciano para esta bóveda el publicado por Lafuente Ferrari (fig. 9) ${ }^{40}$, existe otro con pequeñas diferencias (fig. 10) que nos confirma que el planteamiento general fue reconsiderado en múltiples ocasiones ${ }^{41}$.

Maella abandona la Colegiata el 16 de octubre ${ }^{42}$ acompañado por su cuadrilla de ayudantes ${ }^{43}$. No obstante en el recibo del carruaje que toma para retornar a Madrid ya se indica el carácter provisional de este desplazamiento, «hasta que vuelva a retocar la pintura del quadro grande que ha acabado de pintar» ${ }^{44}$. El valenciano había sido requerido por uno de sus múltiples compromisos en la academia de San Fernando, atender la sala de Principios de Dibujo ${ }^{45}$, privándose por ello a este fresco de su conclusión. En el mes de diciembre se reinstalan los andamios bajo esta bóveda ${ }^{46}$. El artista deseaba perfeccionar alguna de las figuras, aunque probablemente ahora mediante la técnica del temple al acudir acompañado sólo de su moledor

37 Se representa el momento exacto en que San Ildefonso, al visitar la tumba de Santa Leocadia, la ve incorporarse de su sepulcro en reconocimiento a los escritos que el arzobispo de Toledo había consagrado a exaltar la virginidad de la Madre de Dios. El santo toma su velo y corta un trozo con el puñal del rey Recesvinto, para guardarlo como reliquia. Azcárate Luzán, I. y otros. Historia y Alegoría: Los concursos de pintura de la Real Academia de Bellas Artes de San Fernando (1753-1808). Madrid, Real Academia de San Fernando, 1994, p. 64. Este asunto se replanteará más adelante a través de un boceto que se encuentra en el Museo Cerralbo para el claustro de la catedral de Toledo.

${ }_{38}$ Pérez Sánchez, Alfonso E. Catálogo de Dibujos III Dibujos Españoles siglo XVIII C-Z. Madrid, Museo del Prado, 1977, pp. 66-67.

39 Pérez Sánchez, op. cit., p. 67.

40 Este óleo sirvió de base para la reconstrucción que realizó Horacio Ferrer ya en nuestro siglo. La primera vez que se cita este cuadro es atribuído a Ramón Bayeu. Madrid, Sociedad Española de Amigos del Arte: Antecedentes, coincidencias e influencias del arte de Goya: catálogo ilustrado de la exposición celebrada en 1932, 1947. Más adelante es atribuído a Corrado Giaquinto por D’Orsi, op. cit., p. 105. No existen cambios de importancia a excepción de que en la versión definitiva el espacio arquitectónico parece simplificarse y se destaca la representación de la Inmaculada.

${ }^{41}$ Archivo Amatller E-5775. Esta pintura fue reproducida por Morales, op. cit., 1996, p. 21, aunque como el expuesto por la Sociedad Española de Amigos del Arte.

42 «... Aboné al Pintor Maella por el gasto diario que ha hecho asta el dia diez y seis de este mes de octubre segun minuta que dio quatrocientos setenta y cinco reales y medio...». A.C.S.I. Leg. Cuentas n. $31-99$, Octubre 3. Semana.

${ }^{43}$ «Aboné al Oficial del Pintor Maella... Aboné á dos peones del Pintor Maella... Aboné al Moledor del Pintor Maella por ocho días de jornales inclusos dos Domingos por abonarle uno de ellos que tocó en el camino para hirse á Madrid a razón de nueve reales día; quarenta y cinco reales que se le abonaron por las caballerías que le llevaron, y su ropa asta dicho Madrid, con mas diez y. seis reales para su Gasto del camino...». A.C.S.I. Leg. Cuentas n. ${ }^{\circ}$ 31-99, Octubre, 3. ${ }^{\mathrm{a}}$ Semana.

44 A.C.S.I. Leg. Cuentas n. ${ }^{\circ}$ 31-6. Martín, op. cit., p. 253.

45 «Turno de los Señores Directores para la asistencia de los Estudios en el curso, que empieza en 1. ${ }^{\circ}$ Octubre 1771, y acaba en fin de Junio de 1772». Francisco Gutiérrez y Maella son mandados llamar para atender esta sala en el mes de Noviembre. Archivo de la Academia de San Fernando, 21-9/1.

${ }_{46}$ «... Aboné a dicho primer carpintero por una docena de lías para los andamios que segunda vez se hicieron para retocar el Quadro Grande, y un ciento de clavos de tres al quarto todo para dichos andamios...». A.C.S.I. Leg. Cuentas n. ${ }^{\circ}$ 31-83, Diciembre, 1 . $^{\mathrm{a}}$ Semana. 


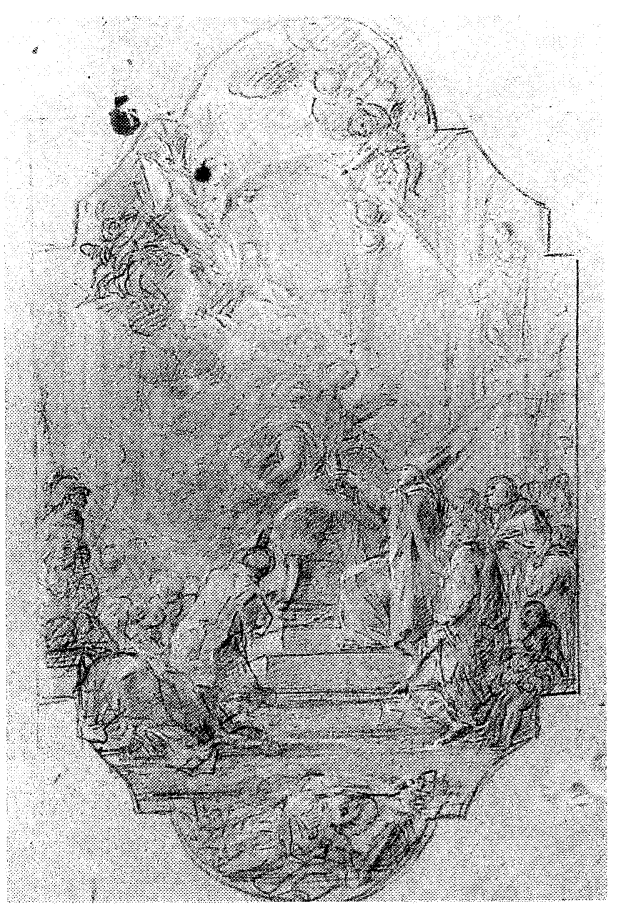

7
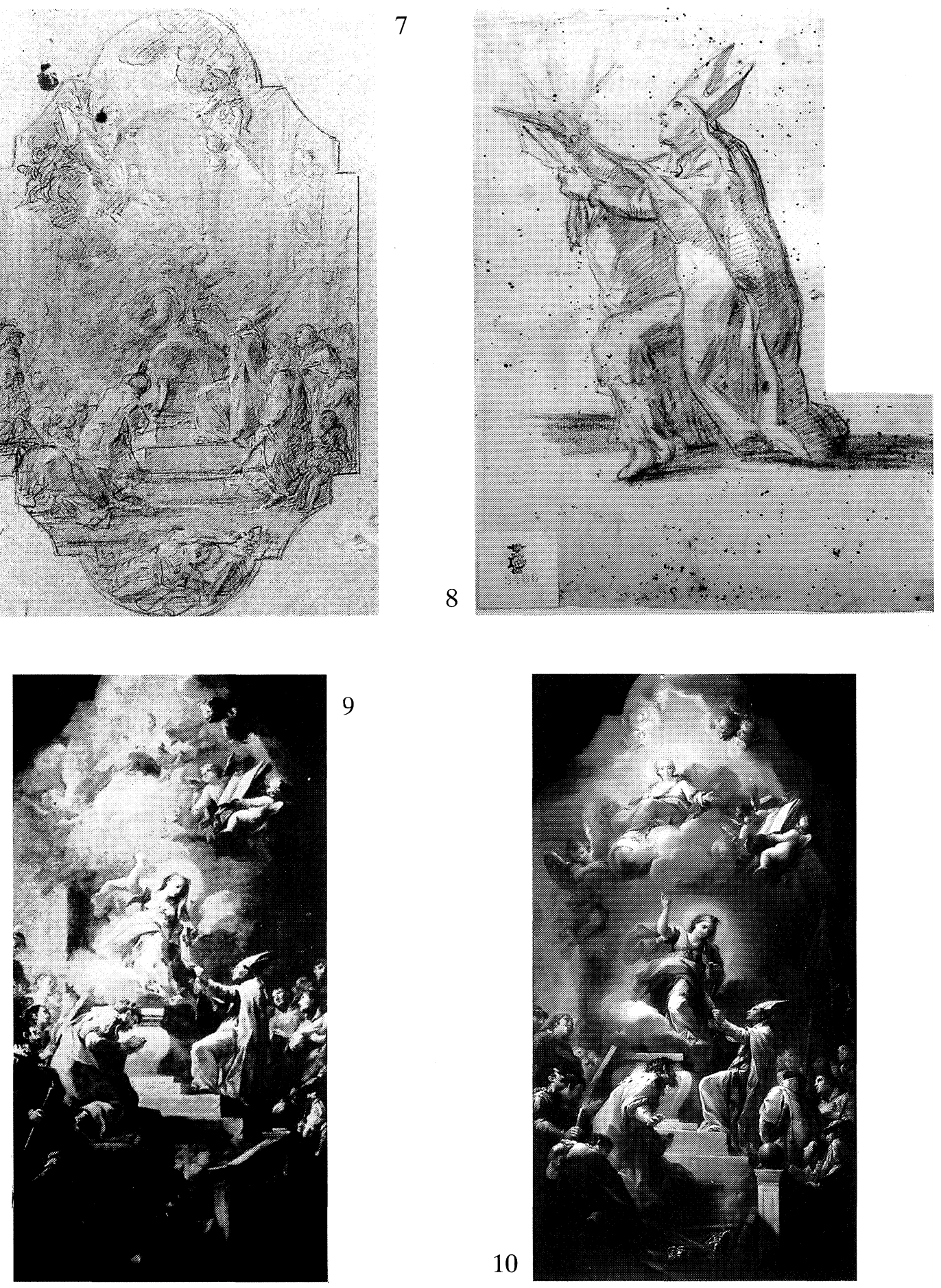

9

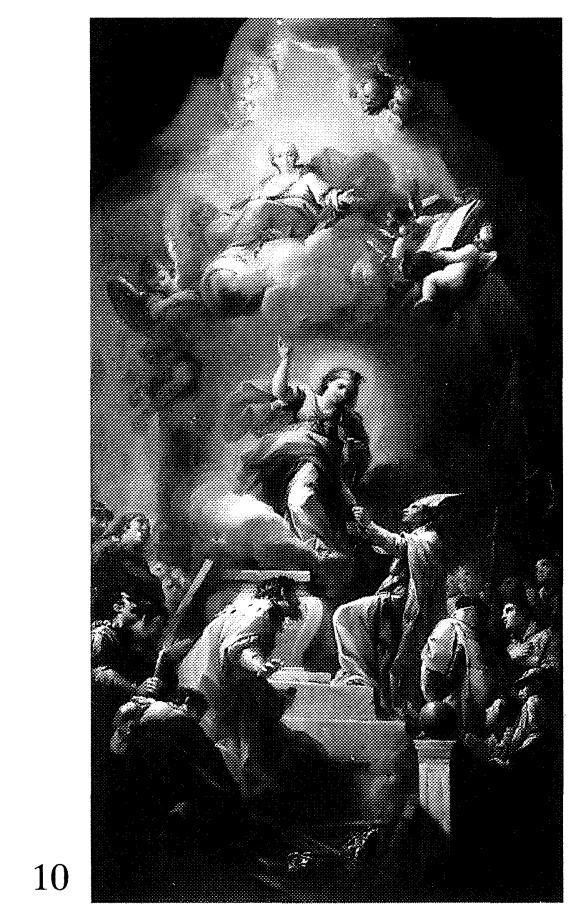

Figura 7. Mariano Salvador de Maella, «Aparición de santa Leocadia a san Ildefonso» (dibujo). Madrid. Museo del Prado.

Figura 8. Mariano Salvador de Maella, «San Ildefonso». Madrid. Museo del Prado.

Figura 9. Mariano Salvador de Maella, «Aparición de santa Leocadia a san Ildefonso». Madrid. Colección particular.

Figura 10. Mariano Salvador de Maella, «Aparición de santa Leocadia a san Ildefonso». Madrid. Colección particular. 
de colores ${ }^{47}$. Esta tercera estancia del pintor en la Granja se extenderá por espacio de 17 días ${ }^{48}$.

El 17 de diciembre Solano revela al cabildo la pretensión de ambos artistas de abandonar la Granja. Al darse a conocer esta noticia los canónigos de inmediato se reconocen «en obligación de ser agradecidos» y proceden a deliberar acerca de la retribución con que se les debía agasajar ${ }^{49}$. Tras dilucidar su cuantía, el día 21 el secretario Bernardo de Quirós lo notifica al apoderado en Madrid con el objeto de que cursara «dichas cantidades á sus respectivas casas» ${ }^{50}$. Algunos días más adelante, Maella rubricaba en su domicilio de la Plazuela de la Cebada un justificante por recibir de «mano del sr. dn. Sebastián de Yndaburu; diez mil reales de vellón» ${ }^{51}$.

Ya desde los albores de su existencia la fortuna no iba a acompañar al ornato de la Colegiata. Expirando ya 1771 y nada más faltar de allí los artistas, el pizarrero Gregorio Martín es requerido para detener una gotera que se estaba filtrando sobre la escena acabada de pintar por Maella hacía tan sólo unos días ${ }^{52}$. Las inclemencias climáticas del lugar ocasionarían constantes restauraciones desde fechas tan tempranas como enero de $1772^{53}$. Esta prematura intervención en las bóvedas parece de esta manera tornase en un aciago augurio de la final privación de todos los frescos de Maella para la sensación ornamental de la Colegiata.

La orden definitiva de desmontar todo el andamiaje no llegará hasta el 24 de enero de 1772, finiquitadas también las labores del dorador Antonio de la Vega ${ }^{54}$. Es en ese instante cuando la renovada decoración del templo, miscelánea de diferentes artes, se vierta ante la mirada de sus canónigos con un efecto realmente impactante. Si los vetustos muros sencillamente encalados brindaban al templo una tremenda atmósfera de frialdad, ahora su interior se ha tornado en una auténtica sinfonía de luz y color. De ahí que en la Colegiata se desate una frenética actividad encaminada a reformar o más bien a adecuar la apariencia de las obras de arte allí existentes a su modernizada ornamentación.

Inmersos ya en la subsiguiente etapa de mejoras se confía a Fermín Huici la talla de dos hornacinas para albergar las imágenes de Nuestra Señora del Rosario y de los Dolores ${ }^{55}$. Al

${ }^{47}$ A.C.S.I. Leg. Cuentas n. ${ }^{\circ}$ 31-83, Diciembre, 2. ${ }^{\mathrm{a}}$ y $3 .^{\mathrm{a}}$ Semana.

48 A.C.S.I. Leg. Cuentas n. ${ }^{\circ}$ 31-83, Diciembre, $4 .^{\mathrm{a}}$ Semana.

49 A.C.S.I. Libro 2. ${ }^{\circ}$ de Acuerdos communes..., ff. 520-520v.

so Muy Sr. mio: Por el Cavildo está acordado que se gratifique á los Pintores de S.M. que se han empleado en nuestra obra, para cuio efecto se dispuso que yo como secretario escriviese á Vm., esta por la qual se servirá mandar poner á la disposicion de Dn. Francisco Bayeu, quince mil reales, y á la de Dn. Mariano Maella, diez mil, que es lo que el Cavildo ha dispuesto se les dé por razon de gratificacion: y tambien se me advierte diga a Vm. que embie dichas cantidades á sus respectivas casas, que por esta, y sus recivos se le abonarán á Vm. dichos veinte y cinco mil reales en las quentas de su cargo. Con este motivo me repito á su disposicion, deseando que logre Vm. felices Pascuas: San Ildefonso 21 de Diciembre de 1771. De orden de el Illmo. Cavildo BLM a Vm. su afecto servidor. Josef Bernardo de Quiros Canonigo Secretario (A.C.S.I. Leg. Correspondencia Apoderados).

51 A.C.S.I. Correspondencia Apoderados. Martín, op. cit., p. 254.

52 «... Aboné á Gregorio Martín Pizarrero de este Sitio por aber quitado una gotera que caia encima del Cuadro del Choro...». A.C.S.I. Leg. Cuentas n. ${ }^{\circ}$ 31-83, Diciembre, 4. ${ }^{a}$ Semana.

53 «... con el motivo de caer una gotera en la Pintura que, ejecutó Maella, havia tratado con el Aparejador de remediarla, y que este decia se necesitaba un escamado de tablas...». A.C.S.I. Libro 2.. ${ }^{\circ}$ de Acuerdos communes..., f. 528. Martín: op. cit., p. 80.

${ }^{54}$ A.C.S.I. Libro Tercero de Acuerdos communes del cavildo de la Insigne, y Real Iglesia Colegial de la S.S. Trinidad de este Real Sitio de San Ildephonso siendo secretario el Dr. dn. Francisco Antonio de Alcocer canonigo de dicha Iglesia y empieza dia veinte y quatro de Enero de mil setescientos, setenta y dos y acaba el 14 de Octubre de 1780, f. 1.

55 A.C.S.I. Libro Tercero de Acuerdos communes..., ff. 146v-147. Manuel García Sánchez, «Maestro Arquitecto de la Villa de Peñafiel» pudo ser la persona que diseñó las urnas para las imágenes (A.C.S.I. Leg. Cuentas n. $\stackrel{0}{35})$. 
escultor francés Roberto Michel, que había estucado las bóvedas, se le comisiona para la creación de las dos pilas de agua bendita emplazadas aún en la actualidad en los accesos de la iglesia ${ }^{56}$. Otra dimensión de este proceso es asimismo la adquisición de nuevos objetos de culto. El pintor Jacinto Gómez, oriundo de San Ildefonso, presentará asimismo un lienzo de Nuestra Señora de la Soledad «para quando se predica el sermón de Soledad» ${ }^{57}$.

Otro de los debates que se entabla entre los canónigos será la exacta ubicación de algunas esculturas que descendidas de sus altares al arranque de las obras permanecían almacenadas para prevenir su deterioro. En conexión con este asunto será la resolución de 28 de febrero de no restituir a su antiguo emplazamiento las tallas de san José y de la Inmaculada Concepción, «hasta que viniendo la Corte se tome a éste fin el parecer del Sor. Marqués de Grimaldi» ${ }^{58}$. Más adelante los religiosos resuelven el 7 de julio, con el monarca residiendo en la Granja, «que los señores comisionados de Corte se viesen con el Sor. Marqués de Grimaldi, y por medio de S.E. solicitasen saber, si el Rey gusta, que las imágenes de Nra. Sra. de la Concepción, y San Joseph se coloquen en la Iglesia» ${ }^{59}$. El día 12 de este mismo mes, Jose Quirós y Manuel Ramón Cáceres ya se habían entrevistado y comunican la resolución de que «no se pusiesen en Altar alguno de la Iglesia la imagen de Nra. Sra. de la Concepción; si solo algun Quadro pequeño de dicha nra. sra. entretanto que don Mariano Maella de orden del Rey formaba otro cuadro grande» ${ }^{60}$.

Al ser interpelado Carlos III sobre la representación de la patrona de España en el interior de la Colegiata, lógicamente la juzgó ya inapropiada en el marco del remozado programa plasmado en sus bóvedas. Sin embargo hasta el 21 de agosto de 1772 Grimaldi no hace partícipe de esta nueva comisión a Maella ${ }^{61}$. Esta Inmaculada es la primera composición conservada de un modelo tan representativo del valenciano que alcanzará en España un gran éxito, desbancando por completo al de coetáneos suyos como Francisco Bayeu y difundiéndose incluso a lo largo de los reinados de diferentes monarcas. Por fortuna se ha conseguido trazar documentalmente con precisión todo su proceso de gestación, pudiéndose extrapolar el estudio de este encargo como interesante muestra del proceso de realización y aceptación de una comisión real en las últimas décadas del siglo XVIII.

${ }^{56}$ Sr. Dn. Galamino, canonigo therorero de Nra. Rl. Igla. de la SSa. Trinidad en este Real Sitio. Sirvasse Vd. en virtud de esta y recibo de Dn. Roberto Michel, Maestro Escultor de camara de S.M. entregarle seis mil y quinientos reales vellón importe de las dos Pilas de Agua Bendita de Nra. Igla., ajustadas en la referida cantidad, a consentimiento de Nro. Illmo. Cabildo, en virtud de la quenta que dí, como constará de acuerdos, pues por esta, tomada la razon de Nro. contador se abonarán a Vd. en quenta General. San Ildefonso y Julio 20 de 1771. Dr. Dn. Phelipe Antonio Solano, canonigo fabriquero (A.C.S.I. Leg. Cuentas n. ${ }^{\circ}$ 31).

Señor don Francisco Presno canonigo thesorero de Nuestra Real Iglesia Colegial, sirvasse Vmd. entregar a don Jacinto Gomez, doscientos reales vellón, los ciento y ochenta son por haver pintado una Nuestra Señora de la Soledad de mi orden, para quando se predica el sermon de Soledad, en dicha Nuestra Iglesia y los veinte restantes, por el marco que se le ha puesto para su adorno, que tomada la razón del contador y recivo del interesado se le abonaran a Vmd. en sus cuentas, San Ildefonso y Septiembre 18 de 1774. Dr. Josef Bernardo de Quirós Canonigo Fabriquero (A.C.S.I. Leg. Cuentas n. ${ }^{\circ}$ 34). Este cuadro puede ser el que se conserva hoy en día en la sala Capitular de la propia Colegiata (óleo sobre lienzo de $72 \times 59 \mathrm{cms}$.).

58 A.C.S.I. Libro Tercero de Acuerdos communes..., f. 8.

${ }^{59}$ A.C.S.I. Libro Tercero de Acuerdos communes..., f. 33.

60 A.C.S.I. Libro Tercero de Acuerdos communes..., f. 33v. A pesar de lo dispuesto anteriormente se decide la realización de unos altares en el Panteón para colocar estas imágenes, lugar donde se encuentran hasta la fecha. En la sesión ordinaria celebrada el 29 de octubre de 1772 «se determinó, que las imágenes de Nra. Sra. de la Concepción, y Sn. Joseph se coloquen en las Puertas que hacen frente á las entradas del Panteon, y que se dispongan del modo mejor dos Altares en que pueda dcirse misa...» (A.C.S.I. Libro Tercero de Acuerdos communes..., f. $39 v)$.

${ }^{61}$ A.G.P. Caja 13.626. 
El 22 de agosto el artista agradece al ministro de Estado este nuevo reto que «he recibido con la mayor beneracion y gusto por el singularísimo honor que en ella se me proporciona» ${ }^{62}$. El pintor no descuidará ni un instante porque ese mismo día contacta también con el secretario de Grimaldi, Bernardo Iriarte. La intención de este segundo escrito no era otra que la de requerir las dimensiones del cuadro «para que arreglado el tamaño y proporción formase la composición» ${ }^{63}$. La corte continuaba aún afincada en San Ildefonso, por lo que Iriarte se las puede proporcionar de inmediato. El funcionario aprovecha también la coyuntura para advertirle en primer lugar acerca de la exigua iluminación de la que se dispone en el altar ${ }^{64} \mathrm{y}$ del interés del monarca por que se incorporen en su lienzo las insignias de la orden de Carlos III, acabada de aprobar hacía tan sólo unos meses por el Papa Clemente XIV ${ }^{65}$.

A la semana siguiente, Maella ya tenía dispuesto un dibujo que sin dilación remite a Grimaldi. Afortunadamente en la correspondencia el propio artista nos brinda una sucinta descripción: «la idea que tomado para manifestar las insignias de la orden ha sido poniendo una figura alegórica que manifieste ser la España en acto de mostrar el collar y banda de la orden, como impetrando auxilio de la Purísima Concepción, por protectora de dicha orden y Patrona de España a el otro lado é puesto el manto enlazado con unas palmas que manifiesta ser la orden distinguida y en el manto se pondrá las cifras de C-III» ${ }^{66}$.

Con este dibujo el artista ya requería el 3 de septiembre al ministro «... me haga el favor de advertirme los defectos que note» ${ }^{67}$. En esta documentación se establece de forma muy explícita que el marqués de Grimaldi es comisionado para filtrar las composiciones de los Pintores de Cámara. Al extrapolar esta circunstancia, puede que este personaje emerga como una de las figuras claves en la configuración definitiva de muchos de los encargos pictóricos cortesanos de las últimas décadas de este siglo ilustrado. Una fascinante vía de investigación queda así abierta en el análisis del exacto papel desempeñado por este ministro, ya que en efecto para esta Inmaculada se ha podido localizar una escueta esquela autógrafa con sus objecciones:

«La Virgen debe mirar a la España.

En vez del mundo debe ponerse la media luna substituyendo tambien algunas nubes sobre las quales esté la Virgen.

Conviene que la España tenga todo el mayor aire posible de ofrecer a la Virgen el collar solo con la cruz pendiente quitando la cinta.

Deberá la España tener el manto carmesí sembrado de castillos y leones.

Deberá quitarse el Escudo de armas y el leon.» ${ }^{68}$

62 Ibidem.

63 Ibidem.

${ }^{64}$ Ibidem.

${ }_{65}$ Rincón García, Wifredo. «Iconografía de la Real y Distinguida Orden de Carlos III». Fragmentos, núms. 12-13-14, Junio 1988, pp. 145-161.

${ }_{66}$ A.G.P. Caja 13.626. Esta distribución de la composición con la alegoría de España arrodillada implorando el favor de la Inmaculada, pudo ser tomada de un libro que se acababa de imprimir en Valencia. El grabado, que sin duda conocería Maella, ilustra a «Mater Immaculata» y se describe en el texto diciendo «... Y como nuestro Catholico Monarca el señor Don Carlos III (que Dios guarde) solicitó, que nuestro Santísimo Padre Clemente XIII la declarase Patrona de España con el honroso título de la Inmaculada Concepción, se pinta esta provincia en figura de una doncella, solicitando su patrocinio, y María Santísima ofreciendoselo». Letania Lauretana de la Virgen Santissima, expressada en cincuenta y ocho estampas, e ilustrada con devotas Meditaciones y Oraciones, que compuso en latín Francisco Javier Dornin, Predicador de Friedberg, y traduxo un devoto. Valencia: Viuda de Joseph de Orga, 1768, pp. 36-37.

67 A.G.P. Caja 13.626.

68 Ibidem. 
Se ha conseguido identificar este primer borrón aquí descrito entre los atesorados en los álbumes de Fernando VII ${ }^{69}$ (Fig. 11). Nada mas restituírsele con las objecciones adjuntas, Maella realiza algunas de las variaciones directamente sobre el propio dibujo aunque muy pronto pasará a concebir otro distinto. Por fortuna este segundo bosquejo se conserva también en la Biblioteca Real y en él se reproduce de forma meticulosa todas las indicaciones de Grimaldi ${ }^{70}$ (Fig. 12). El siguiente peldaño en la consecución de la regia aprobación será tomar los pinceles e interpretar todo ello sobre el lienzo.

$\mathrm{Al}$ analizar el boceto de presentación (fig. 13) ${ }^{71}$ se advierte como en cierta manera se ha vuelto al planteamiento compositivo de partida. Al confrontar esta obra, o una segunda versión conservada asimismo en colección particular ${ }^{72}$ (fig. 14), con el lienzo colocado en la actualidad en el altar de la Granja (fig. 15), descollan nuevas objecciones a su diseño. No obstante la orden de sustituir la alegoría de España por la imagen de san Frutos, intuimos que emana ahora del cabildo y no del monarca. Hasta la fecha no se conservaba memoria alguna de la existencia en el retablo del lado de la Epístola,.futuro emplazamiento del cuadro del valenciano, de otra obra de similares dimensiones que representaba al patrón de Segovia. El cabildo pretendía así no trastocar la advocación de dicho altar.

Esta noticia inédita se ha exhumado de entre las extensas relaciones de gastos originados en el devenir de las reformas. En septiembre de 1770 el carpintero Manuel Matilla ya se persona con un recibo por «bajar los cuadros» ${ }^{73}$. Será Domingo María Sani quien se haga cargo de esta pintura junto con la de san Ildefonso, ubicada en el lado del Evangelio. Tras finalizar las tareas de ornamentación de la Colegiata se le reclama al mencionado aposentador de Palacio su devolución ${ }^{74}$, procediéndose a su reposición en sus respectivos altares con el renovado enmarcaje de estuco con que se les había aderezado ${ }^{75}$.

El hallazgo de este dato viene a afinar y revestir de más coherencia al ciclo iconográfico de los tres altares con que ornamentaba Felipe V la capilla Real concebida para su enterramiento. Por un lado se colocó en el altar mayor un lienzo de Andrea Procaccini personificando a Nuestra Señora del Rosario acompañada por los santos patronos de la familia real ${ }^{76}$. Mientras que en los colaterales se dispondrían probablemente dos del mismo artista con las imágenes de san Frutos, patrón de la diócesis de Segovia, y san Ildefonso del propio Real Sitio. Años más

${ }^{69}$ Biblioteca Palacio Real, Albumes de dibujos de Fernando VII, t. III n.o 5 (226 $\times 139$ mm.). Aunque descirto por Díaz Gallegos: op. cit., t. II, p. 460, como «Inmaculada adorada por un personaje oriental» opinamos que se trata más bien del primer pensamiento para esta comisión.

70 Biblioteca Palacio Real, Albumes de dibujos de Fernando VII, t. II n. ${ }^{\circ} 142(281 \times 195$ mm.). Ibidem, t. II, pp. $460-461$.

${ }^{71}$ Fotografía del Instituto Diego Velázquez n.ำ 35.676 (recuperación 1939-40), como de la colección de Francisco Coello y Pérez del Pulgar, Játiva. Interforma. Subasta de Pintura Antigua. Logroño (27 octubre 1983) (reproducido en portada). Luna, Juan J. «Obras inéditas de Mariano Salvador Maella y otras consideraciones». Fragmentos, núms. 12-13-14, Junio 1988, p. 50. Rincón, op. cit., pp. 156-157. Morales, op. cit., 1996, pp. 107-108.

72 Esta segunda versión atribuída a Maella por Pérez Sánchez, op. cit., p. 59, es de dimensiones más reducidas (60 o $43 \mathrm{cms}$.) y sólo se conoce por una fotografía conservada en el Archivo MAS (G/65.114).

73 A.C.S.I. Leg. Cuentas n. $\stackrel{0}{30-108 .}$

74 «Se determino ne mine discrepante ... que se pidiesen a Dn. Domingo Sani los dos Quadros de Sn. Ildefonso y Sn. Frutos, para colocarlos como estaban». A.C.S.I. Libro 2. ํ de Acuerdos communes..., ff. 501v y 504v.

${ }^{75}$ «... Aboné á Gregorio Martín Pizarrero de este sitio por ... aber ayudado a poner los Cuadros, y Marcos

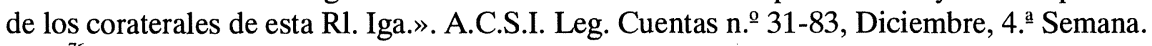

76 Urrea, Jesús. La Pintura Italiana del siglo XVIII en España. Valladolid: Publicaciones del Departamento de Historia del Arte, 1977, pp. 180-181. 


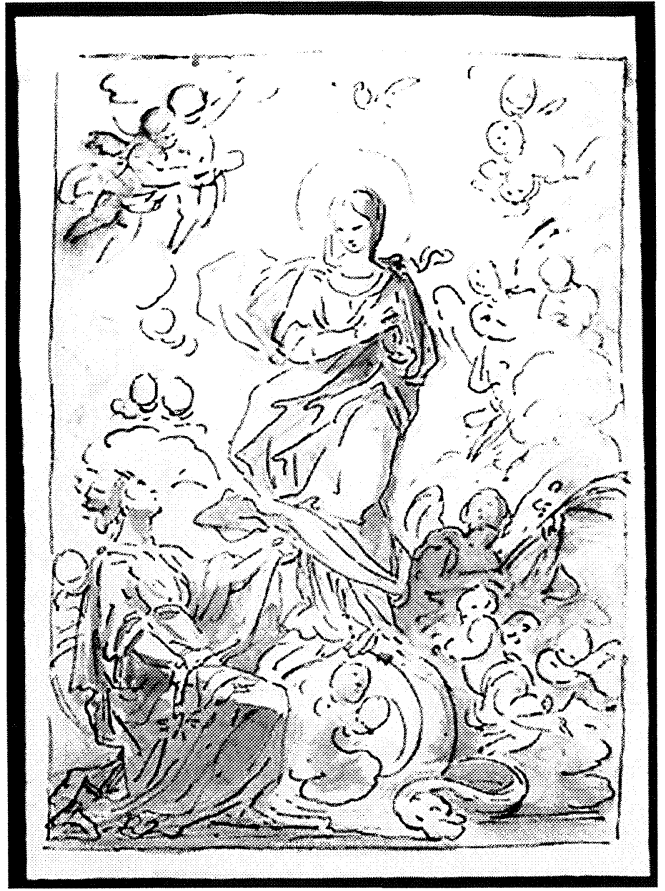

11
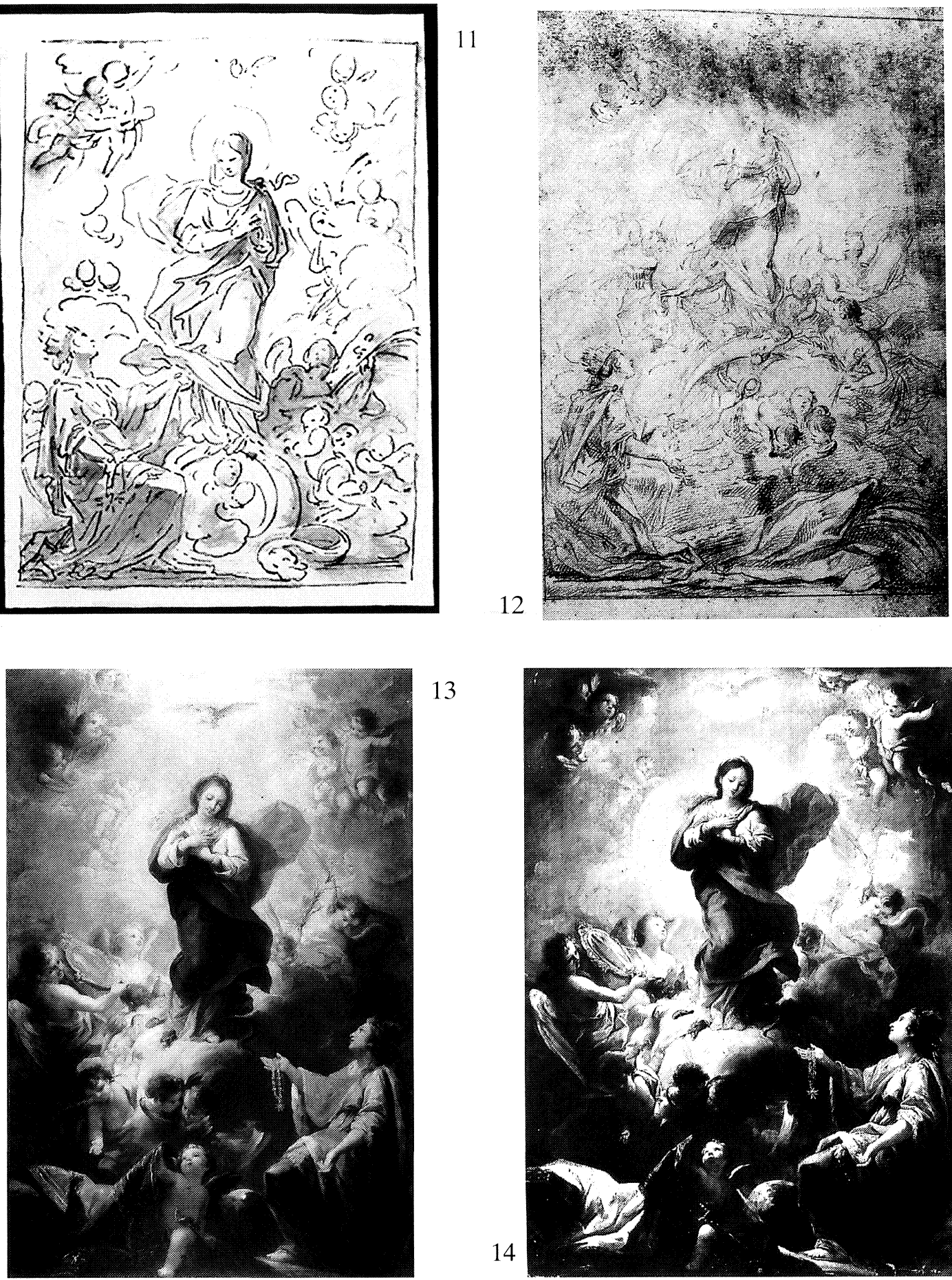

13

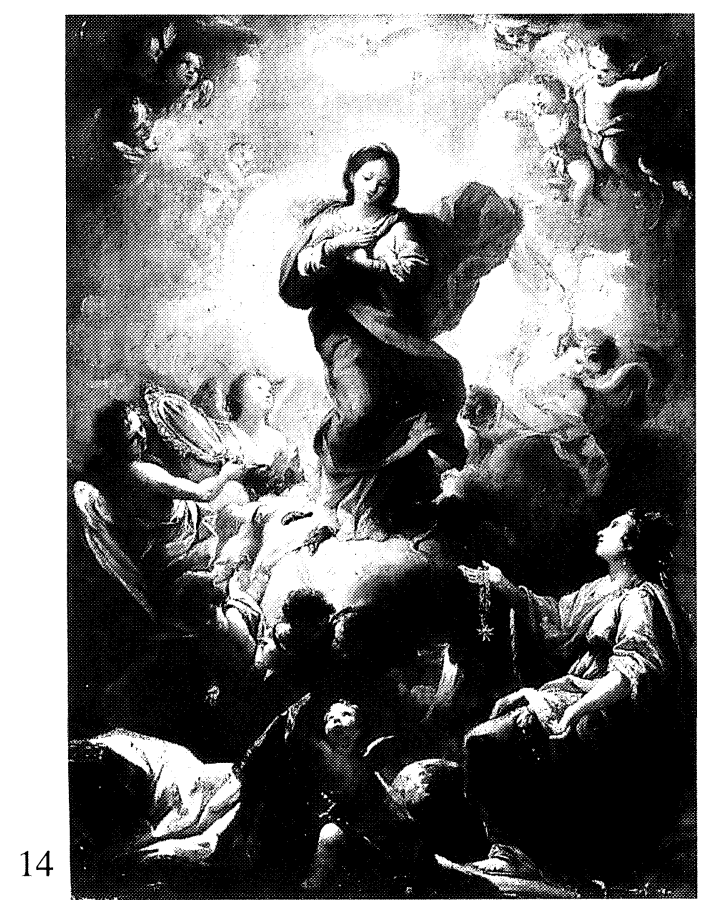

Figura 11. Mariano Salvador de Maella, Inmaculada Concepción con la alegoría de España. Madrid. Biblioteca del Palacio Real.

Figura 12. 'Mariano Salvador de Maella, Inmaculada Concepción con la alegoría de España. Madrid. Biblioteca del Palacio Real.

Figura 13. Mariano Salvador de Maella, «Inmaculada Concepción con la alegoría de España». Madrid. Colección particular.

Figura 14. Atribuído a Mariano Salvador de Maella, «Inmaculada Concepción con la alegoría de España». Madrid. Colección particular. 


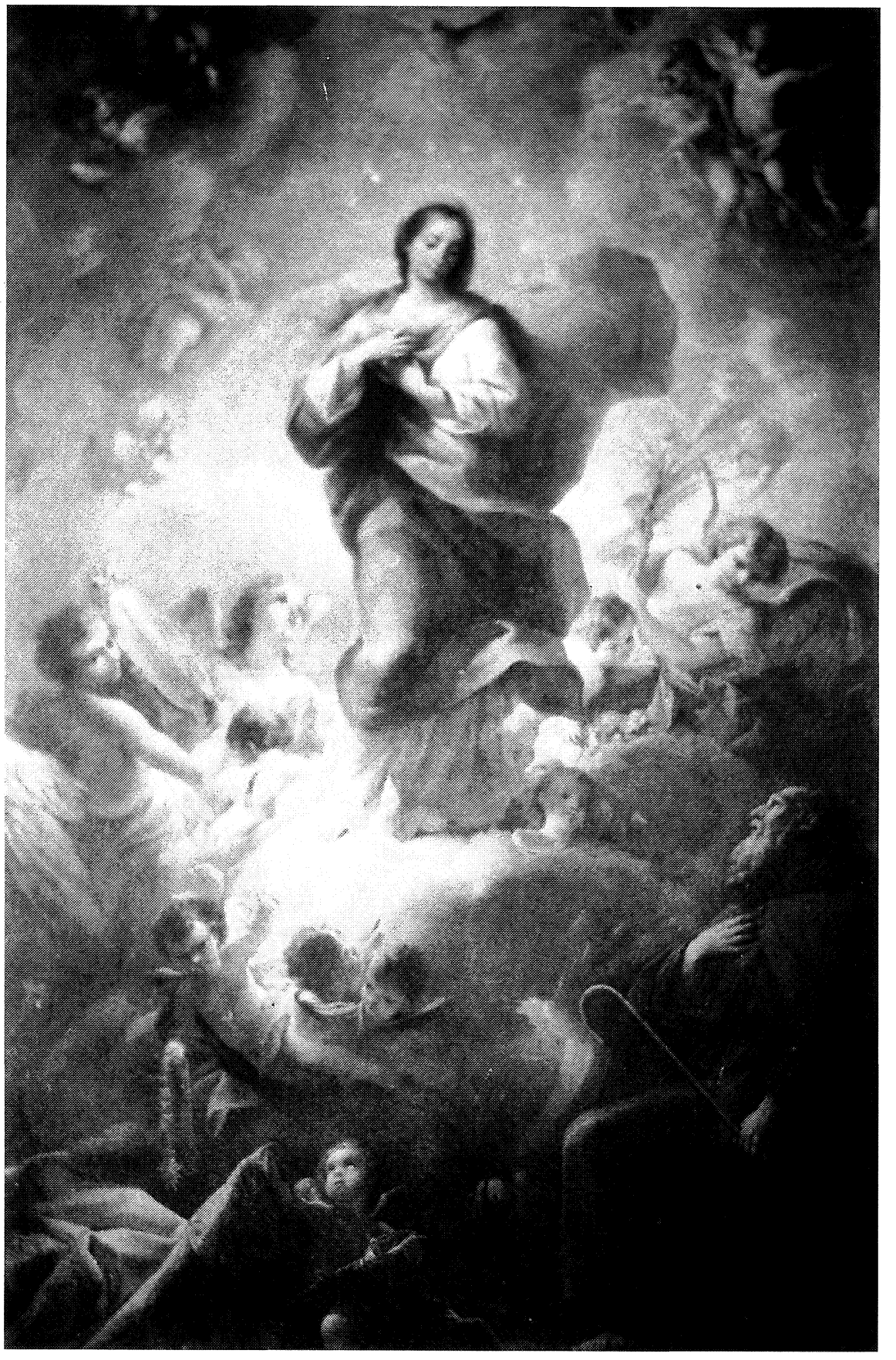

Figura 15. Mariano Salvador de Maella, «Inmaculada Concepción con san Frutos». La Granja. Colegiata de la Santísima Trinidad. 
tarde Carlos III no pretendía más que cerrar este ciclo al representar en las bóvedas a los patrones de España y en la cúpula escenas de advocación del templo ${ }^{77}$.

En el instante mismo de enterarse de su encargo, el valenciano comunica a Grimaldi «ya sabe Vm. tengo encargados tres cuadros para el convento nuebo de Aranjuez y si he de poner mano al quadro de la Concepción será menester dejar los otros para más adelante» ${ }^{78}$. Las obras en las que Maella se hallaba trabajando eran tres grandes lienzos para el convento de san Pascual Baylón de Aranjuez que debían sustituir a los ejecutados hacía escasos años por Giambattista Tiépolo. A los canónigos de esta forma se les reproducía el problema suscitado en la consecución de los frescos, afortunadamente en esta ocasión el monarca concede prioridad a la Colegiata. Solventado este escollo, Maella también demanda «si los gastos de los materiales han de correr por quenta del Rey o del cabildo, y si corre la misma paridad que en la obra del fresco me hará Vm. favor partiparlo a el Sor. fabriquero» ${ }^{79}$. La ornamentación de las bóvedas había sido financiada en su totalidad por esta corporación eclesiástica pero esta Inmaculada constituía un presente de Carlos III.

La incorporación del lienzo de Maella al ornato del templo se materializa hacia la segunda semana del mes de julio de $1774{ }^{80}$. Los comisionados de Corte acuden a dar «las gracias al Exmo. Señor Marqués de Grimaldi, suplicando a S.E. al mismo tiempo hiciese presente a S.M. el agradecimiento y obligación del Cabildo a la honra que acaba de hacerse» ${ }^{81}$. La Inmaculada debió producir un fuerte impacto tanto en el cabildo como en el propio soberano. El 18 de julio los canónigos resuelven que «al Pintor de Camara de S.M. se le regalasen 25 doblones en atención al esmero con que pintó el cuadro de nra. Sra. de la Concepción» ${ }^{82}$. En esta misma sesión Juan Antonio de Cáceres da las órdenes oportunas al tesorero para que se facilitara «a Narciso Sanz, mozo de Fábrica de Nra. Rl. Iglesia, mil quinientos reales de vellón para que entregue a don Mariano Maella» ${ }^{83}$. Por otro lado y de forma independiente Carlos III manda a los administradores de Correos recompensarle por la renta con «15.000 reales de vellón por via de gratificación en atención a haber pintado un cuadro de la Concepción para la colegiata de san Ildefonso» ${ }^{84}$. Ambas recompensas supusieron sin duda para Maella un lisonjero reconocimiento y perfecto colofón a su intervención en la ornamentación interior de esta Real Colegiata de la Santísima Trinidad.

77 Una vez sustituído por la Inmaculada de Maella el Cabildo consideró la posibilidad de «destinar el quadro de San Frutos a alguna Iglesia de la Abadía» aunque finalmente «se le encargó al Sor. Fabriquero le coloque donde mejor le parezca». A.C.S.I. Libro Tercero de Acuerdos communes..., f. 140.

78 A.G.P. Caja 13.626.

79 A.G.P. Caja 13.626.

${ }^{80}$ Señor Dn. Francisco Presno canonigo thesorero de Nra. Rl. Iga. Colegial, sirvase Vmd. entregar a Dn. Miguel Boutelou sacristan de dicha Nra. Iga. cien reales vellón para que los dé de gratificacion a los Peones y carpintero extraordinario, que se busco, para colocar el Quadro de Nra. Sra. de la Concepción, que con el recivo de Dn. Miguel Boutelou, tomada la razon del contador se le abonaran a Vmd. en quentas generales, San Ildefonso y Julio 20 de 1774. Dn. Juan Antonio de Caceres Canonigo Protofabriquero. A.C.S.I. Leg. Cuentas n. ${ }^{34}$. Maella se desplaza a la Granja para estar presente en la instalación de su cuadro. Un recibo de 800 reales por los gastos de este viaje se abonará en Madrid el 30 de julio de 1774. A.G.P. Obras Leg. n. 038.

${ }^{81}$ A.C.S.I. Libro Tercero de Acuerdos communes..., ff. 136v-137.

82 Ibidem.

En 1806 los canónigos Agustín de Cáceres y José Pérez Necochea realizaron un índice de los papeles existentes en el Archivo de la Colegiata de San Ildefonso. En el Cajón 23, Leg. 1.ํoñalan que había bastante documentación sobre esta gratificación pero este legajo no ha podido ser consultado al no conservarse en la actualidad en el Archivo.

83 A.C.S.I. Leg. Cuentas n. 034.

${ }^{84}$ Fechado el 3 de abril de 1775 . A.G.P. Caja 13.626. 